DOI https://doi.org/10.36059/978-966-397-158-2/119-134

\title{
POLITICAL DIALOGUE - A KEY TOOL FOR PROVIDING DEMOCRATIC TRANSIT
}

\section{Pielievin I. Yu.}

\section{INTRODUCTION}

In today's world, where many of the former restrictions are being removed and the field of social interaction is expanding, dialogue (from Greek dialogos - converse, conversation, or exchange of thoughts, negotiations, understanding) is becoming an increasingly popular form of relationship). In the modern sense, dialogue is a certain analogue of public diplomacy as a negotiated procedure with a final agreement. Political dialogue is a path that leads from disputes, differences and conflicts through the stages of joint discussion of problems, convergence of positions and further - to the understanding and cooperation of participants in communication. It is no coincidence that in politics dialogue turns into a norm of civilized cooperation and democratic interaction of the parties, which may differ in terms of views and functional and structural characteristics, but recognize the right to the existence of other, alternative views, opinions, beliefs, values.

As a reasonable alternative to violence, war, terrorism, revolutions, insurrections, riots and other manifestations of political extremism, radicalism, intolerance and intolerancy, dialogue has always occupied and continues to occupy a special place in the processes of democratic transit. In this context, the dialogue in politics should be understood not as a conversation between two or more persons on the subject of political life, but as a certain configuration of interaction, negotiation process and partnership built on the principles of discursive equality between political communication entities seeking to understand and achieving a mutually beneficial result.

Democratization of relations between the state and society, which is an integral part of democratic transit, involves creating an atmosphere of trust and harmony, including through political dialogue between public authorities, citizens and public institutions representing their interests. Dialogue is not just a conversation, but a certain type of social relationship. In the process of dialogue, the participants of communication must not only 
listen and hear each other, but also follow the agreed rules of communication. In this connection, it should be noted that in our country the culture of political dialogue, debate, controversy has not yet received the relevant theoretical knowledge, or the implementation of social and political and administrative practices. Hence, the study of political dialogue in Ukraine is of particular relevance. After all, the formation of a culture of dialogue interaction is the key to the irreversibility of the processes of democratization, the formation of new democratic, legal, social relations between the main actors of the political process.

\section{Political dialogue as a phenomenon of social life and scientific category}

The axiological status of the dialogue is so high that it is rightly on par with such fundamental political values as democracy, freedom, equality and equal rights. From the point of view of contemporary scholars of political discourse, democracy is not so much a set of procedures and their application, but a dialogical interaction between different policy makers the state, parties, NGOs and individuals including. And some of them go further and propose to abandon the vague and meaningless concept of «postmodernism» in favor of characterizing modern times as an «era of multidimensional dialogue», of inclusive and universal dialogue ${ }^{1}$. In this connection, there is a need for optimal disclosure and understanding of the possibilities of political dialogue, as a special form of dialogue, as relations between two or more actors, exchange of opinions, first of all, on sociopolitical and socio-economic topics, search for effective ways of its using.

To achieve this, one should turn to the arsenal of diverse fields of sociohumanitarian knowledge, each of which focuses on particular aspects of dialogue, both as a phenomenon of social being and as a scientific category.

Thus, in the social-philosophical key, such well-known intellectuals as M. Bakhtin, M. Buber, B. Waldelfels, F. Ebner, E. Levinas, G. Marseille, O. Rosenstock-Hussi, F. Rosenzweig and others were engaged in the analysis of public dialogue.

At the beginning of the last century, the philosophy of dialogue offered its own way of acquiring a person its identity, which was lost as a result of the development of industrial society. In this way, dialogue becomes, in fact, a way of reviving spiritual values, a way of returning to eternal You - God (M. Buber, B. Walldelfels, G. Marseille). Famous works of M. Buber «Me and You» ${ }^{2}$ and $\left\langle\right.$ The Problem of Man» ${ }^{3}$ became the first to come up with the

\footnotetext{
${ }^{1}$ Каган М. С. Философия культуры. Санкт-Петербург: Изд-во «Питер», 1996. С. 402-404.

${ }^{2}$ Buber Martin I and Thou. Martino Publishing, 2010. Reprint of 1937. 137 p.
} 
idea of dialogue as a tool to overcome the spiritual crisis of European civilization. Thus, in the paper «The Problem of Man,» M. Buber identifies two major factors that deepened the anthropological crisis of the twentieth century. It is the destruction of social connections and the loss of spirituality. The result of their actualization was the alienation of man both from himself and from the world he created. In order to resolve this contradiction, the philosopher abandons the traditional individualistic and collectivist approaches and proposes to turn to the dialog model «man with man». At the same time, the essence of the Bouber dialogue is realized not in the subjects (participants) of the dialogue, and not in the world where they are near things - objects, but only in the dimension that is accessible only to them and exists between (desswishen) them.

Other representatives of the philosophy of dialogue attach decisive importance not to dialogue relations as such, but to their individual refraction. Thus, the concept of M. Bakhtin's dialogue contains the idea of the enormous importance of «I». The philosopher places the very personality in the center of the universe, and therefore the dialogue takes place not in the interpersonal space (desswishen by M. Buber), but in the space of the categories «I» and «You» ${ }^{4}$.

Creative achievements of M. Buber, M. Bakhtin and others. provided impetus for further development of various concepts of dialogue and interpersonal communication (C. Axelrod, A. Akhiezer, V. Bibler, P. Vermes, S. Gurevich, M. L. Diamond, M. Kagan, G. Pomerantz, M. Friedman and etc.). Thus, in the context of the processes of archaizing the post-modern society, O. Akhiezer explores the problem of social dialogue. The central ideas of his concept are «inversion» and «mediation» as the focus of public consciousness on the past (outdated, archaic, traditional) and future (new, avant-garde, innovative), respectively. The main source of social tension, according to A. Akhiezer, is the clash of archaization (anti-mediation) and the progress that comes before anything between cultural values and lifestyles that differ in their focus on static or dynamics. According to the scientist, in such a situation, the only cardinal means of overcoming social disorganization is the development of dialogue as a system of certain relationships and (sub)culture through the formation of $132 \mathrm{c}$.

${ }^{3}$ Бубер М. Проблема человека; пер. с нем. Киев: «Ника-Центр», «Вист-С», 1998.

${ }^{4}$ Бахтин М. Эстетика словесного творчества. Москва: Искусство, 1979. 424 с. 
appropriate institutions and the development in various diverse social groups of the ability to make joint decisions ${ }^{5}$.

The problematization of the dialogue relations «I - the Other», carried out in classical phenomenology, is elaborated in the concept of «Alien» by B. Waldelfels. He proposes to remove the traditional dichotomy of «His own / Alien» to establish a new «responsive» type of rationality. Its basic concepts («alien», «failure of intentionality», «challenge - answer») are considered as the basic characteristics of modern discourse ${ }^{6}$.

$\mathrm{V}$. Bibler discusses the dialogical nature of human consciousness in his writings on the dialogue of cultures ${ }^{7}$.

In general, the philosophy of dialogue has shown the importance for the existence of a person of dialogical relations as such.

Further analysis of the phenomenon of social dialogue at the level of methodology of social processes cognition, interaction and exchange of information and theory of polyparadigmatic development of science was carried out in the fundamental works of such authors as M. Weber, G.-G. Gadamer, G. Lasswell, J. Mill, J. Ritter, et al.

Thus, M. Weber explores the phenomenon of social dialogue as a kind of social action. The latter is one of the simplest elements of the social system, a unit of sociological analysis. Action, according to Weber, is human behavior that gives the subject some meaning (motivation). A social scientist called an action that, in its sense, puts into it an active individual or group, focused on the corresponding behavior of other accomplices of interaction, that is, on certain expectations. Therefore, according to Weber, social action must have at least two necessary features: first, the subjective motivation of an individual or group, to be aware; second, focused on the past, present or future behavior of others (friends, work colleagues, etc.) ${ }^{8}$. Social actions are caused by dissatisfaction, that is, a mismatch between what a person needs and what he or she needs. Dissatisfaction is manifested in various forms: hunger, material discomfort, anxiety, creative anxiety. The level of dissatisfaction will change if the goal is achieved. The goal is the expected consequence of meeting the need. Formation of a personal goal aimed at

\footnotetext{
5 Ахиезер А. Архаизация как категория общественных наук. Журнал социологии и соииальной антропологии. 2001. Т. 4. № 1.С. 89-100.

${ }^{6}$ Waldenfels B. Phenomenology of the Alien: Basic Concepts (Studies in Phenomenology and Existential Philosophy). Evanston: Northwestern University Press, 2011. 104 p.

${ }^{7}$ Библер В. Мышление как творчество (Введение в логику мысленного диалога). Москва: Политиздат, $1975.400 \mathrm{c}$.

${ }^{8}$ Вебер М. Соціологія. Загально історичні аналізи. Політика; пер. 3 нім. Київ: Основи. 1998. C. 322-346.
} 
meeting one's own needs, taking into account the possible reaction of the environment, is the motive of social action.

Usually purposeful actions are the most likely to solve problems effectively. However, the likelihood of realization of one or another type of motivation for social action depends both on the characteristics of the individual, his culture, education, intellectual capabilities, and on the type of society, socio-cultural environment, the mass distribution of certain types of motivations.

Each society is dominated by one of these several varieties of interaction, and it defines the relations of domination, subordination, as well as the nature of the society itself. The dominance of traditional and affective interactions forms a traditional society, purposeful and value-rational industrial. In order to understand the functioning of society, it is necessary to consider more closely its interaction with individuals, the interaction of individuals and groups themselves.

In particular, G.-G. Gadamer brings the issues of public dialogue into the field of hermeneutical analysis. For him, dialogue is both communication (conversation) and a way to relate the test to the person reading the text. Consequently, the ontological status of the dialogue is refracted in the plane of speech. Hence, the goal of genuine dialogue, at both personal and social levels, is to understand and reach agreement. However, to understand for G.-G. Gadamer is to understand the case itself, not the opinions of others about the case. In this way, the dialogue creates a community that closely connects the rich number of participants with diverse, often opposite positions, into a single communicative space.

\section{The role of dialog communication in the functioning of political systems}

Dialogical issues are actively studied within the framework of the theory of integrative understanding of social structure of society, which is considered in the works of J. Alexander, E. Arato, Y. Habermas, E. Gellner, E. Giddens, J. Kin, J. Kogen, N. Luman, J. McLean, T. Parsons, N. Smelser, A. Toynbee, O. Toffler, T. de Chardin and others.

Thus, N. Luhmann defines power as a means of communication that «differs from other means of communication in that its code requires partners, that is, on both sides of the communicative attitude, to reduce complexity by actions rather than by excitement» ${ }^{9}$. The regulator of such interaction of actors in civil society space should be dialogue, which leads to

\footnotetext{
9 Луман Н. Власть; пер. с нем. Москва: Праксис, 2001. С. 34.
} 
the emergence of generally accepted norms and principles of joint practical interaction.

This view is also reflected in the works of E. Giddens, who emphasized that $\ll \ldots$ in social systems it is vital to recognize the degree of interdependence, because the relations of interdependence are always and everywhere the relations of power. Power in social systems can be interpreted as containing a relationship of reproducible autonomy and dependence in social interaction $\gg{ }^{10}$.

The eminent American researcher, the founder of the systematic approach to the study of society, T. Parsons emphasized the important constructive role of dialog communication in the formation and development of human activity in the functioning of social systems. According to him, «the complexity of systems of human activity is impossible without relatively stable symbolic systems, and the latter are created and function only through communication processes» ${ }^{11}$.

As a philosophical principle that affirms openness in relations at the individual and social levels and serves as a dialogue. It is the dialogue that allows the individual to be «socially responsible», «able to see» (P. Teillard de Chardin), «to accept challenges» (A. Toynbee).

According to $\mathrm{Y}$. Habermas's theory of communicative action, if instrumental action is aimed at success, then communicative action is about mutual understanding of the subjects of communication, their consensus. At the same time, their agreement on the situation and the expected consequences is based on conviction, not coercion. It involves the coordination of the actors`efforts, which are aimed at understanding.

The analysis of social and psychological aspects of dialogue interaction depending on the forms of political order is presented in the works of F. Borkenau, V. Bocheliuk, R. Dahl, A. Inkeles, R. Leventhal, J. Talmon, E. Fromm, S. Huntington, T. Khomulenko etc.

However, the dialogue aspect has not yet been sufficiently elaborated, taking into account the relevance of the democratic model of public policy to the specific parameters of the dialogue.

In spite of the rather thorough developments in the field of the study of dialogue as a form of social communication, represented by social and philosophical knowledge, in the newest theories of management (V. Isaacs, S. Dietz, O. Zaitsev, L. Ellinor, J. Gerard, N. London, W. Lawrence,

\footnotetext{
${ }^{10}$ Гідденс Е. Соціологія; пер. $з$ англ. Київ: Основи, 1999. С. 122.

${ }^{11}$ Парсонс Т. Понятие общества: компоненты и их взаимоотношения. Американская соииологическая мысль: Тексты. Под. ред. В. И. Добренькова. Москва: Изд. Международного ун-та Бизнеса и Управления, 1996. С. 498.
} 
L. Lynn, B. Pearson, J. Simpson, K. Skelcher, S. Heinrich, S. Hill, L. Hoss, $\mathrm{K}$. Hood, etc.) only indicates the need to find new forms and means of interaction of power with the public.

For example, according to the opinion of the American researcher $\mathrm{W}$. Isaacs, the purpose of dialogue is not so much solving problems as «dissolving» them. The dialogue is defined by V. Isaacs in the line of hermeneutics, as a process of communication, purposefully directed to the search, study and formation of understanding. Dialogue creates a space and a way to study and explore the essence of the issue through the analysis of collective and individual ideas, beliefs and feelings. The dialogue is not about changing people's beliefs or behavior, but about informing and teaching them. Dialogue provides opportunities for its participants to listen and be heard; to talk to others and talk respectfully; to develop or deepen mutual understanding; to learn about other thoughts, to talk about your own point of view; to build relationships in a positive way.

For L.K. Hos, the main component of dialogue is the reduction of the level of conflict, as dialogue is a «practice of mediation in competing and conflicting discourses» ${ }^{12}$. L. Ellinor and J. Gerard describe dialogue as a fundamental process of communication that fosters a high level of trust and openness. There are no differences in the dialogue process. Dialogue, from the perspective of these authors, is used to understand the nature of an existing problem.

According to S. Landon, the purpose of the dialogue is not to solve or eliminate the problem, but to «explore the most promising areas for action.» In his view, the dialogue focuses on common interests, not differences ${ }^{13}$.

S. Dietz and J. Simpson believe that dialogue, since the second half of the twentieth century, has become a major feature of society and humanity's hope that it will ever be able to withstand the global challenges of today. Based on the ideas of Y. Habermas and G.-G. Gadamer they has developed a «politically responsive» communication theory (PRCT) of constructionist dialogue, which recognizes the particular importance of political situationalism and understanding of the «other» ${ }^{14}$. For S. Dietz and J. Simpson, the dialogue is organically linked to communication on socially

12 Hawes L. C. The dialogics of conversation: Power, control, and vulnerability. Communication Theory. 1999. № 9. P. 229.

13 London S. The Power of Dialogue. Scott London: website URL: http://www.scottlondon.com/articles/ondialogue.html.

${ }^{14}$ Deetz S., Simpson G. Critical Organizational Dialogue: Open Formation and the Demand of «Otherness». University of Colorado Boulder: website. URL: http://www.colorado.edu/Communication/comm4600880/Deetz. 
significant public issues between stakeholders. According to the researchers, such a dialogue is synonymous with public discussion.

The dialogic theory of public relations is well developed overseas, especially in North America. Along with J. Grunig, a scientist whose name is associated with the emergence of this model, other foreign authors have worked on the same problem and continue to work on it. In the late 1990s and early 2000s, a number of scientists recorded the so-called «dialogical turn» in public relations (Dialogical Turn of Public Relation). Extremely fruitful contribution to the study of the dialog model of public relations was made by K. Bozan, R. Burkart, R. Lipper, R. Pearson and others.

In our opinion, not only the study, but also the implementation of this model in the processes of social power, are extremely relevant for Ukraine. After all, social practice and increase of civic activity of the population testify that traditional socio-cultural models of monologic communication of the state and civil society require modernization, development of feedback mechanisms and institutionalization of new mechanisms of communication of the authorities and society and technologies of communication with the public in the format of symmetrical dialogue.

All this introduces the issue of improving political dialogue in the subject range of current problems of domestic political science. Today, for policy theory, dialogue is a channel for connecting citizens, social communities, civil society institutions, and businesses with public agencies and government. And since democratization implies that subjective and subjective relationships take place between the institutions of state power and civil society, and are not devoid of conflict and competitiveness, since they involve diversity of interests, awareness of the format of dialogue is very important. In this connection there is a need to explore not only the traditional forms of dialogic interaction in politics, but also its new manifestations.

\section{Dialogue of the state and civil society - the communicative basis of democratic transformations in a post-totalitarian society}

The political dialogue of a democratic format is based on a dialogue, parity and contractual basis, based on general democratic principles, the use of which reflects the general level of development of the state and civil society. On this basis, the main purpose of political dialogue is to involve society in the process of public policy implementation through regulation of socio-economic and socio-political development.

The necessary components of the dialogue structure are: a) the actors, b) the subject of the discussion, c) the space of action, d) the time of the 
action. Each of these elements has its own «dialogical» features. In addition, the dialogue also has other characteristics, which include: a) the position of the actors of the dialogue; b) high energy of the field of interaction (which presupposes expressiveness and effectiveness of positions and parties); c) deep conditionality of the dialogue with the degree of historical development of individuals, society, etc. In this context, the dialogue is, first and foremost, a special type of communication that involves the active interaction of equal actors.

Dialogue is a social phenomenon, because it is first and foremost a contact of people. Dialogue in communication is characterized by the perception of the opponent as comfortable, at least not as uncomfortable, indicating that there is at least a minimal element of unity between the participants of the dialogue. The content of human communication is the achievement of some consensus necessary for any social community to coexist with others. Features of social dialogue, unlike its individualpersonal and group varieties, are more conditioned not so much by personal characteristics, gender, professional or ethnic structure of the population, but by the objective conditions of human existence. That is why public dialogue is of great importance in ensuring the social stability of the society as a whole.

Therefore, public dialogue is the most important functional characteristic of society. It is realized in all forms of interpersonal relationships and interactions, both explicit and implicit. It is, first and foremost, a dialogue between civil society and the state. The first delegates its powers to the second, alienating from the constant dispatch of power functions. It can be said that the degree of civilization of the society is largely determined by the extent to which the dialogue between civil society and the state is open and equal.

It is important that the dialogue between the state and civil society, being one of the varieties of political dialogue, at the same time often acts as social (in the broad sense) or civil (public) dialogue. This dialogue involves not only institutional subjects, actors or policy agents (state, political parties, political leaders, political technologists, etc.) but also ordinary citizens, public associations and non-profit organizations of the third sector.

This tendency is quite clear in the practice of interaction between the authorities and civil society institutions in the developed democracies of the West and some countries of the East. Today, in the face of changing confrontation between the state and civil society, distrust and alertness towards civil society institutions, the need for cooperation and interaction is 
gradually coming to fruition, the broadening of the public sphere, the institutionalization of civil dialogue and public engagement in civil society.

In this connection, it should be noted that in political theory and practice, these processes were often accompanied by criticism of the liberal model of democracy, where the central moment for a long time remained electoral procedures and the formation of a representative system of exercise and functioning of power, which led to alienation of broad sections of society from real participation of society politics, reduced voter activity, loss of legitimacy of the government and its decisions. The solution was found to combine the values of electoral democracy with the mechanisms and procedures of participatory democracy and deliberative democracy of discourse. In fact, the latter significantly expanded and institutionalized numerous dialogues and practices. The mechanisms and technologies of public relations (PR) in the field of political and public administration have been supplemented by GR-technologies, where the public (third sector) and business (second sector) have already initiated interaction, communication and dialogue with the state, government and authorities (the first sector).

At the end of XX - beginning of XXI century, many normative ideas of participatory democracy and deliberative dialogic discourse, which previously seemed utopian, as well as many effective mechanisms and technologies of symmetrical and equal PR and GR - communication in the mode of dialogue, were further developed in the communicative practices of «open government», «e-state» and «e-democracy». Today, relational networking communities with horizontal dialogues and relationships are actively shaping the new networked civil society. Such a society is beyond the control and not subject to the state. But at the same time, it does not oppose it, and will continue to play an increasingly prominent and essential role in the real political process, both within the state itself and internationally.

It is the new interactive media operating on-line in the sphere of Internet space that have become a real alternative to the unified information policy of autocratic regimes, which build communication with the society on the principle of domination of the interests of the state, on the information monopoly, which is reproduced in the form of power, on advocacy and total control over the information agenda, on manipulative technologies of informing citizens and forming public opinion. Moreover, the absence of a full-fledged dialogue between the authorities and the society, effective mechanisms of feedback from the authorities and the public, deprive the government of responsiveness, make it inert, routine, incapable of timely response to the transformation of public opinion and political sentiment in society. 
As the current political situation shows, in some countries, communication technologies that were actively used in the mid-twentieth century during the Cold War have not fully exhausted their militaristic potential and continue to be used in the latest political communications. Former forms and genres of political communication demanded by the authorities themselves still prefer not dialogue, but monologue, not interaction, but influence, not argumentation, but manipulation, not deliberation, but orders, commands or instructions.

And there is some explanation for this. After all, politics is still in some cases the most competitive field of activity, dominated not by the desire for cooperation, agreement, compromise, consensus and dialogue, but the desire to win at any cost. At the same time, the intention to hold power is viewed not so much as competition, contest, rivalry, but as irreconcilable struggle, hostility or even war. In this paradigm of understanding politics and political power, dialogue is pushed out of the political process and viewed as a manifestation of political romanticism has nothing to do with «real politics» and genuine political interests.

In fact, politics involves both competition and consent, which can be implemented in the form of various types of public dialogue, which are a reasonable alternative to violence, bloodshed and civil strife. Thus, it is the real, not the simulative, dialogue that can transform any, even the most acute, socio-political conflict from which all parties can benefit and enjoy. So, the dialogue of the conflict type (rallies, protests, polemics, debates, discussions, etc.) will be replaced by a cooperative type dialogue (negotiations, consultations, hearings, examinations, public control, etc.).

The process of public dialogue implies the availability of tools and mechanisms to enable government agencies and authorities to be more fully informed about the opinions of ordinary citizens. Social dialogue is one of the types of political dialogue aimed at preventing social divisions and deepening mutual understanding, improving interaction and building constructive cooperation between different strata of society. Such dialogue is a continuous, ongoing and improved communication process, involving both representatives of all levels of government and ordinary citizens, both employers and employees. The multilateral and inclusive nature of public dialogue is the objective necessity of creating in the society and the state an atmosphere of trust, openness, readiness for inclusion in an institutionalized system of information exchange.

In general, dialogue in society can be defined as an intersubjective way of publicly expressing socio-political views, opinions, judgments and evaluations of the subjects of communication, whereby understanding and agreement between the participants in the discourse are achieved. Ideally, all stakeholders involved in the topic or issue under discussion should be participants. These are: 1) those on whom decision-making on the problem 
depends; 2) those who can block these decisions; 3) those whose life will be affected by the decisions made on the issue under discussion.

Political dialogue is an important factor in the dynamics of sociopolitical development of society and the modernization of society. At the same time, it is very important that the actors of the dialogue are representative (would have the authority for appropriate communication) and autonomous (financially, organizationally and politically independent both from the state, from business, as well as from foreign sponsors).

An open and full-fledged political dialogue is characterized by the activity of discussion and expression of different points of view with elements of discussion by all its participants. And the peculiarity of the political dialogue is that the act of speaking by one of the participants implies the act of listening and understanding when it is obligatory to change the roles in this interpersonal interaction.

However, it should always be remembered that dialogue or negotiations between government and the public is a tool, but not a strategy for achieving change. Dialogue in itself is not a panacea and its outcome depends on the extent to which its subjects are relevant to their mission, how capable they are, and ready for a full rather than simulating dialogue. It is through dialogue, not ultimatum, or other means of manipulative pseudo-borrowing.

Obviously, the transition from the traditional «vertical» influence to the interaction-dialogue in the relations between the authorities and the public is a key condition for the implementation of a democratic project in transition societies. This involves uniting the creative efforts of government officials and civil society as direct actors of political dialogue.

\section{CONCLUSIONS}

To sum up all of the above, let's try to make some generalizations.

1. Dialogue is an extremely complex, multifaceted and multi-aspect phenomenon. It is no accident that attention is drawn to the dialogue of such political science-related sciences as philosophy, sociology, theory of public administration, cultural studies, psychology, history, logic, anthropology, as well as a number of other disciplines: communication science, management, PR (public relations), pedagogy, philology, rhetoric, religious studies, journalism and more. Philosophers view dialogue in terms of its epistemological, ontological, heuristic, cognitive and methodological aspects. Sociologists' dialogical discourse is interested in the problems of understanding, interpretation and social construction of reality. Dialogue in terms of sociology is the socio-cultural basis of society and the most important means of communication and resolution of social conflicts in society. For cultural scientists, dialogue is of particular value as a way of tolerant coexistence and peaceful interaction between different cultures («dialogue of cultures»), as well as a form of creativity and self-expression 
in the field of art. Psychologists are trying to break into the psychology of interpersonal dialogic interaction. Educators see in the dialogue a humanistic model and method of upbringing and learning. PR and advertising experts view dialogue as the most productive way of establishing mutually beneficial communication with society. For the theory of government, dialogue is a channel for establishing links between public organizations, civil society institutions, and business with government agencies and government.

2. From the standpoint of political theory, the axiological status of the dialogue is so high that it is rightly on par with such fundamental political values as democracy, freedom, equality and equal rights. The prerequisites for political dialogue are political pluralism, political tolerance and communicative competence, the ability to listen, understand and to meet each other for peace, stability and overcoming differences.

3. Dialogue interaction is a form of social interaction and is a form of social dialogue. The latter is the most important functional characteristic of modern society and is implemented in all forms of interpersonal relationships and interactions, both explicit and implicit. As a form of social dialogue, political dialogue is, first and foremost, a dialogue between civil society and the state, which results in the transfer to civil society of some of its powers of the state and control over their implementation. The degree of civilization of a society is largely determined by the extent to which the dialogue between civil society and the state is open and equal.

4. The basic principles of political dialogue as a form of social interaction are the following: mutual assistance with complete independence of the subjects; efficiency in relation to responsibility; transparency and openness in information sharing and planning. Political dialogue is based on a dialogue, parity and contractual basis, based on common democratic principles, the use of which reflects the overall level of development of the state and civil society. In this case, the main purpose of political dialogue is to involve society in the process of regulating socio-economic and sociopolitical development.

5. In Ukraine, the study of political dialogue is of particular importance in connection with the formation of new democratic, legal, social relations between the main social groups, where the leading role belongs to civil society institutions, to achieving their equal interaction with public authorities. Today, in Ukraine, previous monologic relations in the sphere of political interaction as communication between the state and civil society, as a dialogic interaction between the authorities and the individual, are being substantially transformed into dialogical. Former administrative-command, monologue-propaganda methods of managing the society are no longer working, and dialogue is a common practice not only within the civil society itself (in the virtual space of Internet communications), but also in the sphere 
of communication of public institutes with the authorities at the central, regional and local levels. In the process of dialogue interaction, there is symbolic interpenetration and even mediated by the dialogic unity of the fusion of the subjects of communication, that is, hermeneutic - cognitive understanding and mutual understanding of each other by the subjects of dialogue.

6. One of the key conditions for deepening the processes of democratization and establishing a model of democratic governance in Ukraine both at the national and local levels is the legitimate, dynamic and voluntary cooperation of the state with civil society. The main mechanism of implementation of this model is the extension of the communicative (dialogical) space. It is the constant dialogue that ensures mutual understanding and constructive cooperation of the state with civil society. The active role of all parties involved in communication and the willingness, desire and ability of the parties to interact, based on the principles of mutual responsibility on the one hand, and the desire to solve problems independently, play a major role in the process of establishing a dialogue between the authorities and the public. Important in this is both the strengthening of public initiative institutions and the role of nongovernmental organizations, civil society as a whole.

7. The most effective practices for establishing a constructive dialogue between society and the government are contained in the arsenal of participatory democracy, which, in combination with the mechanisms of representative democracy, will be able to ensure that the interests of citizens and social groups are maximally taken into account when making socially significant decisions and public participation in society. Only under such conditions it is possible to guarantee the irreversibility of democratic transformations that Ukraine took the path in 1991.

\section{SUMMARY}

The article is defined the specificity of dialogue as a phenomenon of social existence on the basis of theoretical and methodological approaches within the framework of philosophy, sociology, psychology, philology, cultural studies, theory of public administration, political science and a number of other disciplines. Specific characteristics of dialog communication in the functioning of political systems are given. It is proved that dialogue interaction is a form of social interaction and is a form of social dialogue. The latter is the most important functional characteristic of modern society and is implemented in all forms of interpersonal relationships and interactions, both explicit and implicit. As a form of social dialogue, political dialogue is, first and foremost, a dialogue between civil society and the state, which results in the transfer to civil society of some of its powers of the state and control over their implementation. The main purpose of political 
dialogue is to involve society in the process of regulating socio-economic and socio-political development.

It is determined that one of the key conditions for deepening the processes of democratization and establishing a model of democratic governance in Ukraine both at the national and local levels is the legitimate, dynamic and voluntary cooperation of the state with civil society. The main mechanism of implementation of this model is the extension of the communicative (dialogical) space. The most effective practices for establishing a constructive dialogue between society and government are contained in the arsenal of party-democracy, which, through its combination with mechanisms of representative democracy, will ensure that the interests of citizens and social groups are maximally taken into account when making socially significant decisions and public participation in society.

\section{REFERENCES}

1. Buber Martin I and Thou. Martino Publishing, 2010. Reprint of 1937. $137 \mathrm{p}$.

2. Deetz S., Simpson G. Critical Organizational Dialogue: Open Formation and the Demand of «Otherness». University of Colorado Boulder: website.

URL:

http://www.colorado.edu/Communication/comm4600880/Deetz.

3. Ellinor L., Gerard G. Dialogue: Rediscover the Transforming Power of Conversation. London: Wiley, 1988. 416 p.

4. Habermas Jü. Theorie des kommunikativen Handelnsю Bd. 1: Handlungsrationalität und gesellschaftliche Rationalisierung; Bd. 2: Zur Kritik der funktionalistischen Vernunft. Frankfurt am Main, 1981. $1216 \mathrm{~s}$.

5. Hawes L. C. The dialogics of conversation: Power, control, and vulnerability. Communication Theory. 1999. № 9. P. 229-264.

6. Isaacs W. Dialogue and the Art of Thinking Together: A Pioneering Approach to Communicating in Business and in Life. Bantam Doubleday Dell Publishing Group, 1999. 428 p.

7. London S. The Power of Dialogue. Scott London: website URL: http://www.scottlondon.com/articles/ondialogue.html.

8. Waldenfels B. Phenomenology of the Alien: Basic Concepts (Studies in Phenomenology and Existential Philosophy). Evanston: Northwestern University Press, 2011. 104 p.

9. Ахиезер А. Архаизация как категория общественных наук. Журнал сочиологии и сочиальной антропологии. 2001. Т. 4. № 1. C. $89-100$.

10. Бахтин М. Эстетика словесного творчества. Москва: Искусство, 1979. 424 с.

11. Библер В. Мышление как творчество (Введение в логику мысленного диалога). Москва: Политиздат, 1975. 400 с. 
12. Бубер М. Проблема человека; пер. с нем. Киев: «НикаЦентр», «Вист-С», 1998. 132 с.

13. Вебер М. Соціологія. Загально історичні аналізи. Політика; пер. 3 нім. Київ: Основи. 1998. 534 с.

14. Гадамер Х.-Г. Истина и метод. Основы философской герменевтики; пер. с нем. Москва: Прогресс, 1988.704 с.

15. Гідденс Е. Соціологія; пер. $з$ англ. Київ: Основи, 1999. 726 с.

16. Каган М. С. Философия культуры. Санкт-Петербург: Изд-во «Питер», 1996. 415 с.

17. Луман Н. Власть; пер. с нем. Москва: Праксис, 2001. 256 с.

18. Парсонс Т. Понятие общества: компоненты и их взаимоотношения. Американская соииологическая мысль: Тексты. Под. ред. В. И. Добренькова. Москва: Изд. Международного ун-та Бизнеса и Управления, 1996. С. 494-526.

19. Тейар де Шарден П. Феномен человека; пер. с фран. Москва: ООО Изд-во АКТ, 2002. 553 с.

20. Тойнби А. Постижение истории: Сборник; пер. с англ. Москва: Прогресс. Культура, 1996. 607 с.

Pielievin I. Yu., $\mathrm{PhD}$ in History, Assistant Professor, Department of Political Science, Odessa National Polytechnic University 1, Shevchenko av., Odessa, 65044, Ukraine 